\title{
A method to estimate the biomass of Spirulina platensis cultivated on a solid medium
}

\author{
Lúcia Helena Pelizer ${ }^{1}$, Iracema de Oliveira Moraes ${ }^{2}$ \\ ${ }^{1}$ Departamento de Engenharia de Alimentos (DEA), Programa de Mestrado Profissional em Inovação \\ Tecnológica (PMPIT), Instituto de Ciências Tecnológicas e Exatas (ICTE), Universidade Federal do \\ Triângulo Mineiro, Uberaba, Minas Gerais, Brazil. \\ ${ }^{2}$ Probiom Tecnologia Pesquisa e Desenvolvimento Experimental em Ciências Físicas e Naturais Ltda, \\ Campinas, SP, Brazil.
}

Submitted: May 15, 2013; Approved: March 14, 2014.

\begin{abstract}
This paper presents a method to estimate the biomass of Spirulina cultivated on solid medium with sugarcane bagasse as a support, in view of the difficulty in determining biomass concentrations in bioprocesses, particularly those conducted in semi-solid or solid media. The genus Spirulina of the family Oscillatoriaceae comprises the group of multicellular filamentous cyanobacteria (blue-green microalgae). Spirulina is used as fish feed in aquaculture, as a food supplement, a source of vitamins, pigments, antioxidants and fatty acids. Therefore, its growth parameters are extremely important in studies of the development and optimization of bioprocesses. For studies of biomass growth, Spirulina platensis was cultured on solid medium using sugarcane bagasse as a support. The biomass thus produced was estimated by determining the protein content of the material grown during the process, based on the ratio of dry weight to protein content obtained in the surface growth experiments. The protein content of the biomass grown in Erlenmeyer flasks on surface medium was examined daily to check the influence of culture time on the protein content of the biomass. The biomass showed an average protein content of $42.2 \%$. This methodology enabled the concentration of biomass adhering to the sugarcane bagasse to be estimated from the indirect measurement of the protein content associated with cell growth.
\end{abstract}

Key words: Spirulina platensis, solid state cultivation, estimative of biomass, sugarcane bagasse, protein content.

Agroindustrial wastes used as raw material for generating energy or products of interest are important objects of study for sustainable economic development. Insofar as the development of bioprocesses is concerned, the application of solid supports for growing biomass is attractive, since projects involving the use of immobilized biomass provide substantial economic and environmental benefits, allowing for the implementation of a smaller physical area, and rendering feasible and/or reducing downstream costs. The solid supports used in bioprocesses are usually of synthetic or mineral origin. With regard to agroindustrial wastes, several studies have proposed alternatives for their use as supports and/or substrate (Cunha et al., 2012; Dhillon et al., 2012; Macedo and Santana, 2012; Pelizer and Moraes,
2012; Santos et al., 2012; Zhu et al., 2012). This group of projects involving the use of agroindustrial wastes has included studies focusing on the so-called solid-state fermentation.

Spirulina (blue-green microalgae) is usually cultivated in shallow tanks with natural or artificial lighting and its biomass doubles in 2 to 5 days (Pulz and Scheibenbogen, 1998).

According to Auria et al. (1995), process of solidstate fermentation (culture) involves the growth of microorganisms on moist solid substrates in the absence of free water. The necessary moisture is present in absorbed or complexed form in the solid matrix.

Send correspondence to L.H. Pelizer. Department of Food Engineering, Institute of Technological and Exact Sciences, Universidade Federal do Triângulo Mineiro, Av. Doutor Randolfo Borges Júnior 1250, 38064-200 Uberaba, MG, Brazil. E-mail: lucia.pelizer@gmail.com. 
Estimating biomass can be considered one of the main difficulties in solid-state culture systems because it cannot be determined directly, unlike cultures in liquid media. This difficulty may limit studies focusing on the development of the process, since it precludes studies of the cell growth kinetics. Huang et al. (1985) list a number of methodologies used in the culture of microorganisms on solid culture medium for the determination of biomass. All the cited methods refer to indirect estimates such as the determination of DNA content, glucosamine levels, protein content and the carbon dioxide evolution rate. According to these authors, the direct determination of biomass as it is done in submerged cultures is not feasible in solid cultures due to the difficulty of separating the biomass from the culture medium.

Desgranges et al. (1991a, 1991b) used a large number of hand-operated biochemical methods based on the estimation of glucosamine, total sugars, ergosterol, and carbohydrate consumption. They also used online measurements based on infrared analyses of all components and the carbon dioxide evolution rate to estimate biomass in the culture of Beauveria bassiana by solid-state fermentation in a clay matrix.

Abdullah et al. (1985) estimated biomass content based on the protein content of cultured material determined by the Kjeldahl method, and reported that the biomass of Chaetomium cellulolyticum contained 50\% protein. Sargantanis et al. (1993) also estimated biomass content by determining protein, and concluded that $1 \mathrm{~g}$ of Rhizopus oligosporus cells contained $0.2758 \mathrm{~g}$ of protein. Gutiérrez-Rojas et al. (1995) studied the production of citric acid through solid-state fermentation by Aspergillus niger. They estimated the production of biomass from the determination of protein content by comparison with a control culture on Petri dishes.

According to Auria et al. (1995), some parameters that are indirectly related to biomass and microbial growth, such as increased temperature, exit gas composition, $\mathrm{pH}$ evolution, and pressure drop can be measured online.

In their studies of hyaluronic acid depolymerization, Macedo and Santana (2012) cultured Streptococcus zooepidemicus in apple peel bagasse. To measure the biomass and product, they used the leaching process to remove cellular material, which was determined based on dry weight after separation of the acid produced.

Dhillon et al. (2012) studied the production of hemicellulase and cellulase by Aspergillus niger cultured on apple bagasse. Zhu et al. (2012) examined the production of lipopeptides by Bacillus amyloliquefaciens XZ-173 in solid-state fermentation, using soy flour and rice bran as supports. In both studies, bacterial growth was measured by counting the colony-forming units.

No studies have been published about the cultivation of microalgae on solid medium, so the method proposed here enables estimates the biomass of $S$. platensis grown on solid medium using sugarcane bagasse as support.

In this study, the biomass of $S$. platensis grown on solid medium, using sugarcane bagasse as a support for growth, was estimated by determining the protein content by the Kjeldahl method.

Microorganism and inoculum: The microorganism used in this study was $S$. platensis. The inoculum was prepared in standard mineral medium (Paoletti et al., 1975) and cultured for seven days in Erlenmeyer flasks on an incubator shaking at $160 \mathrm{rpm}$, with $6 \mathrm{k}$ lux lighting and a temperature of $30^{\circ} \mathrm{C}$, as described by Pelizer et al. (2003).

Culture: The $S$. platensis was cultured on solid medium composed of sugarcane bagasse ground in a Wiley mill with $0.5 \mathrm{~mm}$ mesh mixed with standard mineral medium (Paoletti et al., 1975) and supplemented with nutrient $\operatorname{agar}(8 \mathrm{~g} / \mathrm{L})$. The proportion of bagasse in the medium was $1.2 \%$ ( $0.6 \mathrm{~g}$ bagasse $/ 49.4 \mathrm{~g}$ medium $)$. This culture medium had an initial moisture content of $95.8 \%$.

The composition of the standard medium was $\left(\mathrm{g} . \mathrm{L}^{-1}\right)$ : $\mathrm{NaCl}: 0.92 ; \mathrm{Na}_{2} \mathrm{SO}_{4}: 1.88 ; \mathrm{K}_{2} \mathrm{HPO}_{4}: 0.50 ; \mathrm{Na}_{2} \mathrm{CO}_{3}$ : 8.89; $\mathrm{NaHCO}_{3}: 15.15 ; \quad \mathrm{CaCl}_{2} .2 \mathrm{H}_{2} \mathrm{O}: \quad 0.05 ; \quad \mathrm{KNO}_{3}: 2.57$; $\mathrm{MgSO}_{4} \cdot 4 \mathrm{H}_{2} \mathrm{O}: 0.25$; Fe-EDTA solution: $1 \mathrm{~mL} \cdot \mathrm{L}^{-1}$ and trace element solution: 1 mL.L ${ }^{-1}$ (composition (g.L ${ }^{-1}$ ): $\mathrm{H}_{3} \mathrm{BO}_{3} .4 \mathrm{H}_{2} \mathrm{O}: 2.86 ; \mathrm{ZnSO}_{4} .7 \mathrm{H}_{2} \mathrm{O}: 0.222 ; \mathrm{NaMoO}_{4} .2 \mathrm{H}_{2} \mathrm{O}$ : 0.390; $\mathrm{MnSO}_{4}$ : 1.543; $\mathrm{CuSO}_{4} .5 \mathrm{H}_{2} \mathrm{O}$ : 0.079; $\mathrm{CoCl}_{2} .6 \mathrm{H}_{2} \mathrm{O}$ : 0.038 g.L $\left.{ }^{-1}\right)$.

Erlenmeyer flasks containing $50 \mathrm{~g}$ of culture medium were inoculated and incubated at $30{ }^{\circ} \mathrm{C}$ under $6 \mathrm{k}$ lux lighting. The concentration of inoculum was $0.15 \mathrm{~g}$ biomass. $\mathrm{kg}^{-1}$ of moist culture medium. The culture was monitored for 7 days to determine the protein content of the cultured medium by the Kjeldahl method (conversion factor used was 6.25 g protein. $\mathrm{g}^{-1}$ nitrogen) and the moisture content by gravimetry (AOAC, 1984).

Estimation of biomass: To estimate the biomass, $S$. platensis was grown on surface culture medium (standard mineral culture medium and nutrient agar - $8 \mathrm{~g} / \mathrm{L}$ ) in Erlenmeyer flasks at $30{ }^{\circ} \mathrm{C}$ under $6 \mathrm{k}$ lux lighting. Samples were removed from day 3 to day 7 of the process. To this end, surface of each Erlenmeyer flask was washed with distilled water, thereby removing the biomass produced. The material thus obtained was filtered through a polyester membrane with $50 \mu \mathrm{m}$ mesh diameter. The wet biomass retained on the filter was dried at $55^{\circ} \mathrm{C}$ for $12 \mathrm{~h}$ (Pelizer et al, 1999). The total protein content of the dry biomass was evaluated to determine the influence of culture duration on this parameter. The protein and moisture content data were used to estimate the biomass. The flowchart of the process in Figure 1 illustrates the procedure used to estimate the biomass.

In this culture, the protein content of the biomass grown in Erlenmeyer flasks on surface medium was examined daily to check the influence of culture time on the protein content of the biomass. The biomass showed an 


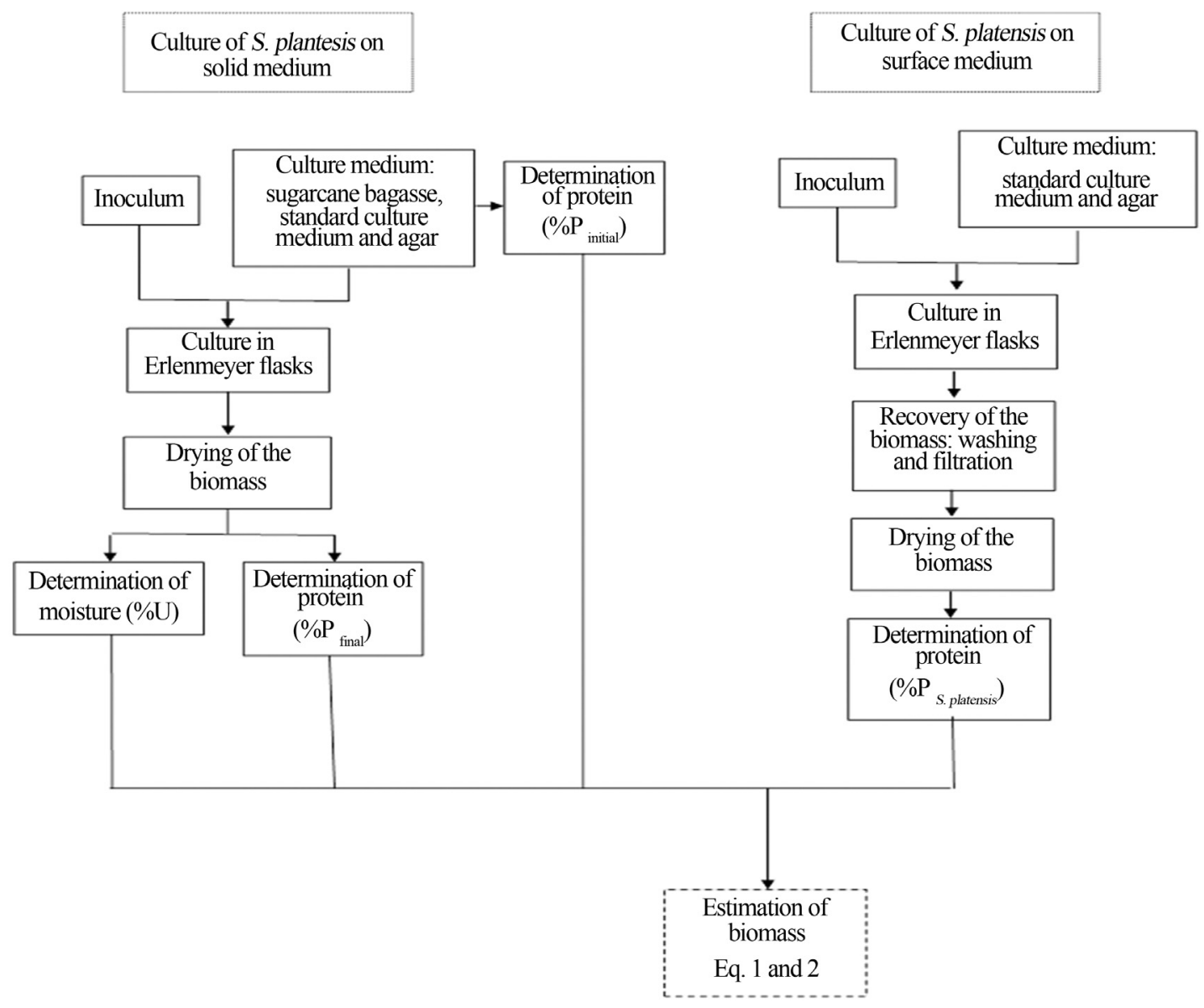

Figure 1 - Flowchart of the S. platensis culture process and estimation of biomass.

average protein content of $42.2 \%( \pm 0.18)$. The analyses were made in triplicate.

The biomass produced on each day of the culture process on solid medium was calculated using Eqs. (1) and (2),

$$
\mathrm{P}_{\text {produced }}=\mathrm{P}_{\text {final }}-\mathrm{P}_{\text {initial }}
$$

where: $\mathrm{P}_{\text {produced }}$ : quantity of protein $(\mathrm{g})$ produced on $100 \mathrm{~g}$ of dry culture medium ( $\left.g_{\text {protein. }} .100 \mathrm{~g}_{\text {dry culture medium }}{ }^{-1}\right) ; \mathrm{P}_{\text {final }}$ : protein content of dry culture medium at a given moment of the process - $\left(\mathrm{g}_{\text {protein }} .100 \mathrm{~g}_{\text {dry culture medium }}{ }^{-1}\right) ; \mathrm{P}_{\text {initial }}$ : protein content of dry culture medium at the beginning of the process - $\left(g_{\text {protein. }} .100 \mathrm{~g}_{\text {dry culture medium }}{ }^{-1}\right)$

$$
\mathrm{B}_{\text {produced }}=\frac{\mathrm{P}_{\text {produced }}}{\mathrm{P}_{\text {S. plantesis }}} \cdot \frac{(100-\mathrm{U})}{10}
$$

where: $\mathrm{B}_{\text {produced }}=$ Produced biomass estimated from the protein content of the culture medium ( $\mathrm{g}_{\text {biomass }} \cdot \mathrm{kg}$ moist culture medium $\left.^{-1}\right) ; \mathrm{P}_{\text {S.platensis }}=$ protein content of $S$. platensis grown on surface medium ( g protein. $_{\text {biomass }}{ }^{-1}$ ); $\mathrm{U}=$ moisture content of the culture medium $\left(\mathrm{g}_{\mathrm{H} 2 \mathrm{O}} \cdot \mathrm{g}_{\text {culture medium }}{ }^{-1}\right.$ )

Table 1 - Results obtained in the cultivation of S. platensis on solid medium.

\begin{tabular}{lccccc}
\hline Time (days) & Moisture (\%) & Protein (\%) & $\begin{array}{c}\mathrm{P}_{\text {produced }} \\
\left(\mathrm{g} .100 \mathrm{~g}^{-1} \text { dry medium) }\right.\end{array}$ & $\begin{array}{c}\mathrm{B}_{\text {produced }} \text { (g.100 } \mathrm{g}^{-1} \mathrm{dry}_{\text {medium})} \\
\left(\mathrm{g} . \mathrm{kg}^{-1} \mathrm{~B} \text { moist medium) }\right.\end{array}$ \\
\hline 0 & $95.8( \pm 0.3)$ & $2.47( \pm 0.04)$ & 0.00 & 0.36 & 0.15 \\
3 & $95.7( \pm 0.3)$ & $2.64( \pm 0.03)$ & 0.17 & 0.40 & 0.17 \\
4 & $95.3( \pm 0.2)$ & $3.21( \pm 0.03)$ & 0.74 & 1.75 & 0.82 \\
5 & $95.2( \pm 0.3)$ & $3.47( \pm 0.03)$ & 1.00 & 2.37 & 1.14 \\
6 & $94.3( \pm 0.2)$ & $5.18( \pm 0.02)$ & 2.71 & 6.42 & 3.66 \\
7 & $94.1( \pm 0.2)$ & $4.51( \pm 0.02)$ & 2.04 & 4.83 & 2.85 \\
\hline
\end{tabular}


To exemplify, a calculation was made of the quantity of biomass produced on the seventh day of the process (Table 1).

If the initial protein content was $2.47 \%$ and the final content was $4.51 \%$, this means that $2.04 \mathrm{~g}$ of protein were produced for every $100 \mathrm{~g}$ of dry culture medium during the process. Since the protein content of S. platensis is $42.2 \%$, $1 \mathrm{~g}$ of S. platensis contains $0.422 \mathrm{~g}$ of protein. The production of $2.04 \mathrm{~g}$ of protein indicates a biomass content of $4.83 \mathrm{~g}$ of S. platensis in each $100 \mathrm{~g}$ of dry culture medium. Given that the moisture of the cultivated material is $94.1 \%$, each $1 \mathrm{~kg}$ of moist culture medium contains $59 \mathrm{~g}$ of dry material. Therefore, $2.85 \mathrm{~g}$ of $S$. platensis.kg of moist culture medium $^{-1}$ were produced.

This method enabled us to determine the cell growth curve of S. platensis cultivated on solid medium, using the results obtained (Table 1).

Based on these data, a kinetic study of the process was performed in terms of cell growth and a subsequent comparison with the culture in liquid medium. The culture in Erlenmeyer flasks using standard mineral medium yielded about $1.5 \mathrm{~g}$ of biomass. $\mathrm{L}^{-1}$ in approximately 14 days of culture (Pelizer et al., 1999). Using the solid-state technique, $3.66 \mathrm{~g}$ of biomass.kg of moist culture medium ${ }^{-1}$ were obtained.

This method of biomass estimation was proposed based on the work of Abdullah et al. (1985), Sargantanis et al. (1993), and Gutiérrez-Rojas et al. (1995), who used a standard culture on surface medium in Petri dishes.

No studies have been published about the cultivation of microalgae on solid medium, so the method proposed here enables estimates to be made of the biomass of $S$. platensis grown on solid medium using sugarcane bagasse as support.

This methodology enabled the concentration of biomass adhering to the sugarcane bagasse to be estimated from the indirect measurement of the protein content associated with cell growth.

\section{Acknowledgments}

The authors gratefully acknowledge the Brazilian research funding agency FAPESP (São Paulo Research Foundation) for its financial support of this research.

\section{References}

Abdullah AL, Tengerdy RP, Murthy VG (1985) Optimization of solid substrate fermentation of wheat straw. Biotechnol Bioeng 27(1):20-7.

AOAC Association of Official Analytical Chemists (1984) Official methods of analysis of the Association of Official Analytical Chemists, 14th ed. Arlington.
Auria R, Ortiz I, Villegas E, Revah, S (1995) Influence of growth and high mould concentration on the pressure drop in solidstate fermentations. Process Biochem 30 (8):751-756.

Cunha FM, Esperança MN, Zangirolami TC, Badino AC, Farinas CS (2012) Sequential solid-state and submerged cultivation of Aspergillus niger on sugarcane bagasse for the production of cellulose. Biores Technol 112:270-274.

Desgranges C, Vergoignan C, Georges M, Durand A (1991a) Biomass estimation in solid state fermentation. I. Manual biochemical methods. Appl Microbiol Biotechnol 35:200-205.

Desgranges C, Vergoignan C, Georges M, Durand, A (1991b) Biomass estimation in solid state fermentation. II. On-line measurements. Appl Microbiol Biotechnol 35:206-209.

Dhillon GS, Kaur S, Brar SK, Verma M (2012) Potential of apple pomace as a solid substrate for fungal cellulase and hemicellulase bioproduction through solid-state fermentation. Ind Crop Prod 38(2):6-13.

Gutiérrez-Rojas M, Córdova J, Auria R, Revah S, Favela-Torres E (1995) Citric acid and polyol production by Aspergillus niger at high glucose concentration in solid state fermentation on inert support. Biotechnol Lett 17:219-222.

Huang SY, Wang CH, Malancy GW, Tanner RD (1985) Kinetic responses of the Koji solid-state fermentation process. In: Wiseman, A. (ed) Topics in Enzyme and Fermentation Biotechnology. John Wiley \& Sons, New York, pp 88-108.

Macedo AC, Santana MHA (2012) Hyaluronic acid depolymerization by ascorbate effects and solid-state cultivation of Streptococcus zooepidemicus in cashew apple fruit bagasse. World J Microb Biotechnol 28:2213-2219.

Paoletti C, Pushparaj B, Tomaselli L (1975) Ricerche sulla nutrizione minerale di Spirulina platensis. Atti Cong Naz Soc Ital Microbiol, Padova, pp 17.

Pelizer LH, Danesi ED, Rangel CO, Sassano CEN, Sato S, Moraes IO (2003) Influence of inoculum age and concentration in Spirulina platensis cultivation. J of Food Eng 56:371-375.

Pelizer LH, Moraes IO (2012) Influence of Water Activity on Production of Bacillus thuringiensis by Solid-state Fermentation. J of Food Sc and Eng 2:326-335.

Pelizer LH, Sassano CEN, Carvalho JCM, SATO S, Gioielli LA, Moraes IO (1999) Padronização do método de secagem da biomassa de Spirulina platensis. Farm. \& Quím 3:54-57.

Pulz O, Scheibenbogen K (1998) Photobioreactors: design and performance with respect to light energy input. Adv Biochem Eng/Biotechnol 38:123-152.

Santos TC, Gomes DPP, Bonomo RCF, Franco M (2012) Optimization of solid-state fermentation of potato peel for the production of cellulolytic enzymes. Food Chem 133:12991304.

Sargantanis J, Karim MN, Murphy VG, Ryoo D (1993) Effect of operating conditions on solid substrate fermentation. Biotechnol Bioeng 42:149-158.

Zhu Z, Zhang G, Luo Y, Ran W, Shen Q (2012) Production of lipopeptides by Bacillus amyloliquefaciens XZ-173 in solid-state fermentation using soybean flour and rice straw as the substrate. Biores Tech 112:154-260.

All the content of the journal, except where otherwise noted, is licensed under a Creative Commons License CC BY-NC. 